\title{
SEJARAH PERKEMBANGAN KURIKULUM DI INDONESIA SEJAK AWAL KEMERDEKAAN HINGGA SAAT INI
}

\author{
Farah Dina Insani \\ farahinsani007@gmail.com \\ UIN Sunan Kalijaga Yogyakarta
}

\begin{abstract}
This article aims to describe the history of the development of the Indonesian education curriculum from 1945 to the present. Curriculum improvements are carried out at least once every ten years. Because within the past ten years, it is very possible that there will be changes in various fields such as information, communication technology and science. The method used in this research is the documentation method as used in data collection techniques in library research (library research). The object of study in this article is focused on tracing the history of curriculum development in Indonesia from the beginning of independence to the present. The results of this study indicate that the curriculum in Indonesia has been developed twelve times, namely in 1947, 1952, 1964, 1968, 1973, 1975, 1984, 1994, 1999, 2004, 2006 and 2013. The positive contribution expected from this article is that the public is educated on the history of curriculum development in Indonesia and can be used as a basis for future curriculum development to create quality students who are ready to compete internationally.
\end{abstract}

Keywords: History, Curriculum, Indonesia.

\begin{abstract}
Abstrak
Artikel ini bertujuan untuk mendeskripsikan sejarah perkembangan kurikulum pendidikan Indonesia sejak tahun 1945 sampai saat ini. Perbaikan kurikulum sekurang-kurangnya dilaksanakan sekitar sepuluh tahun sekali. Karena dalam kurun waktu sepuluh tahun ini, sangat mungkin terjadi perubahan dalam berbagai bidang seperti teknologi informasi komunikasi dan ilmu pengetahuan. Metode yang digunakan dalam penelitian ini adalah metode dokumentasi sebagaimana yang digunakan dalam teknik pengumpulan data pada penelitian kepustakaan (library research). Objek kajian pada artikel ini terfokuskan pada penelusuran sejarah perkembangan kurikulum di
\end{abstract}


Indonesia dari awal kemerdekaan hingga saat ini. Hasil penelitian ini menunjukkan bahwa kurikulum di Indonesia telah dikembangkan sebanyak dua belas kali yaitu pada tahun 1947, 1952, 1964, 1968, 1973, 1975, 1984, 1994, 1999, 2004, 2006 dan 2013. Kontribusi positif yang diharapkan dari artikel ini ialah masyarakat teredukasi terhadap sejarah perkembangan kurikulum di Indonesia serta dapat dijadikan dasar pengembangan kurikulum mendatang untuk menciptakan peserta didik yang berkualitas dan siap bersaing secara Internasional.

\section{Kata Kunci: Sejarah, Kurikulum, Indonesia.}

\section{A. Pendahuluan}

Kurikulum menjadi bagian terpenting pendidikan. Searah dengan kemajuan pendidikan yang terus meningkat pada semua jenis dan jenjang pendidikan di Indonesia. Secara resmi, kurikulum sejak zaman Belanda sudah diterapkan di sekolah, artinya kurikulum sudah diterapkan sejak saat penjajahan Belanda.. ${ }^{1}$ Kurikulum adalah alat yang digunakan untuk menggapai tujuan pendidikan dan sebagai rujukan didalam pelaksanaan pendidikan. Kurikulum menunjukkan dasar atau pandangan hidup suatu bangsa. Bentuk kehidupan yang akan digunakan oleh bangsa tersebut akan ditentukan oleh kurikulum yang digunakan di negara tersebut. $^{2}$

Kurikulum selalu ada perubahan dan penyempurnaan karena banyak faktor yang mempengaruhinya. Tujuan pendidikan dapat berubah secara menyeluruh jika negara tersebut sedang mengalami perubahan dari negara dijajah menjadi negara merdeka. ${ }^{3}$ Opini masyarakat "ganti menteri ganti kurikulum” namun kenyataanya bukan seperti itu. Kenyataraanya perubahan kurikulum adalah bentuk sebagai pengaruh dari perubahan undang-undang tentang sistem pendidikan nasional, misalnya seperti Rencana Pelajaran 1950 merupakan konsekuensi lahirnya UU

${ }^{1}$ Fitri Wahyuni, Kurikulum dari Masa Ke Masa, Jurnal, Al-Adabiya, Vol. 10 No. 2, Juli Desember 2015.

${ }^{2}$ Lismina, Pengembnagan Kurikulum di Sekolah dan Perguruan Tinggi, (Ponorogo : Tim Uwais Inspirasi Indonesia, 2019), hlm. 1.

${ }^{3}$ S. Nasution, Asas-asas Kurikulum, (Jakarta : PT Bumi Aksara, 2006), hlm. 251. 
Nomor 4 Tahun 1950 dan kurikulum 1994 merupakan konsekuensi dari lahirnya UU Nomor 2 Tahun 1989. ${ }^{4}$

Melihat fenomena diatas penulis tertarik untuk meneliti dan menulis karya tulis ilmiah ini yang akan diberi judul "Sejarah Perkembangan Kurikulum di Indonesia dari Masa Kemerdekaan Hingga Sekarang (Kurikulum 1947 Kurikulum 2013) karena dengan kita mengetahui sejarahnya bisa membandingkan satu kurikulum dengan kurikulum yang lain.

\section{B. Metode Penelitian}

Metode yang digunakan dalam penelitian ini adalah metode dokumentasi sebagaimana yang digunakan dalam teknik pengumpulan data pada penelitian kepustakaan (library research). Metode dokumentasi adalah mencari data dan informasi dari benda-benda atau dokumen-dokumen seperti majalah, buku-buku, notulen rapat catatan harian dan sebagainya. ${ }^{5}$

Mengumpulkan sumber-sumber primer maupun skunder yang berupa buku yang ada sangkut-pautnya dengan tema pembahasan pada makalah ini adalah teknik yang digunakan peneliti untu mengumpukan data. Menggunakan metode bertujuan agar mendapatkan data dan penjelasan mengenai pembahasan tema makalah secara terperinci.

\section{Pembahasan}

\section{Perubahan Kurikulum Suatu Keharusan}

Perubahan dan perkembangan zaman sangat cepat, demikian juga perbaikan dan penyelesaian masyarakat pun semakin meningkat. Satuan pendidikan harus disetujui berbagai perubahan dan pemulihan tersebut. Surakhmad dalam bukunya Alhamuddin yang berjudul "Politik Kebijakan Pengembangan Kurikulum di Indonesia Sejak Zaman Kemerdekaan Hingga Reformasi 1947-2013” menyebutkan akan terjadi perubahan yang sangat

${ }^{4}$ Suparlan, Tanya Jawab Pengembangan Kurikulum \& Materi Pembelajaran, (Jakarta : Remaja Rosdakarya, 2011), hlm. 92.

${ }^{5}$ Suharsimi Arikunto, Prosedur Penelitian Suatu Pendekatan Praktek, (Jakarta : Rineka Cipta, 1997), hlm. 149. 
mutlak dalam berbagai bidang. Dia mengatakan pula bahwa gaya hidup manusia, moral, seni dan agama akan sangat dipengaruhi oleh ilmu pengetahuan dan tenologi karena keduannya berada di posisi central. ${ }^{6}$

Pertama, kompetisi dan persaingan hidup antara bangsa-bangsa tidak akan terbatas pada bidang ekonomi saja, namun terjadi pada bidang lain seperti bidang budaya dan ideologi. Kedua, perkembangan ilmu pengetahuan yang meningkat, nilai-nilai moral dan agama akan langsung tertantang, dan sebaliknya akan meningkatkan sistem nilai "beri" yang berbeda dari apa yang diketahui sampai saat ini. Ketiga, pengaruh teknologi yang meningkatkan pola hidup manusia sehari-hari, teknologi tidak lagi terbatas sebagai masalah para ahli teknologi tetapi meluas menjadi masalah etis dan estetis yang memerlukan reinterpretasi dan rekontekstualisasi kebijakan, sosial, dan juga masyarakat awam. Keempat, yang diharapkan ini akan muncul sebagai kenyataan yang tidak bisa dianggap remeh. Sekolah harus berkewajiban untuk menyiasati satinya. Surakhmad menambahkan tidak ada negara buah yang sedang berkembang yang dapat bertahan melawan perubahan dan persaingan seperti yang disebutkan di atas, tidak sesuai dengan diri sendiri, karena itu, ne-gara-negara maju lebih antisipatif, produktif, oleh karena itu mereka lebih siap dan sesuai dengan kondisi yang lebih menguntungkan. Negara-negara berkembang harus segera mengambil sikap untuk diundang.

\section{Sejarah Perkembangan Kurikulum di Indonesia}

Kurikulum di Indonesia setelah Indonesia merdeka pada tahun 1945 telah mengalami 9 kali perubahan diantaranya adalah pada tahun 1947, 1952, 1964, 1968, 1975, 1984, 1994, 2004, 2006 dan 2013. Berbeda dengan itu, kemendikbud memaparkan tentang sejarah perkembangan kurikulum yaitu : perkembangan kurikulum terdiri dari pertama kurikulum 1947, kedua kurikulum 1954, ketiga kurikulum kurikulum 1968, keempat kurikulum 1973 (Proyek Perintis Sekolah Pembangunan), kelima kurikulum 1975, keenam kurikulum 1984, ketujuh kurikulum 1994, kedelapan kurikulum 1997 (revisi

6 Alhamuddin, Politik Kebijakan Pengembangan Kurikulum di Indonesia Sejak Zaman Kemerdekaan Hingga Reformasi 1947-2013, (Jakarta : Kencana, 2019), hlm. 132. 
kurikulum 1994), sembilan kurikulum 2004 (Kurikulum Berbasis Kompetensi), kesepuluh kurikulum 2006 (Kurikulum Tingkat Satuan Pendidikan), kesebelas kurikulum 2013. ${ }^{7}$ Perubahan orientasi, desain, model dan lain sebagainya dengan tujuan utama untuk meningkatkan mutu dan kualitas pendidikan nasional serta mensejajarkan dengan pendidikan-pendidikan yang ada di dunia.

\section{Masa Orde Lama (1945 - 1965)}

\section{a. Kurikulum 1947, “Rentjana Pelajaran 1947”}

Pada masa kemerdekaan muncul kurikulum yang namanya yaitu kurikulum 1947 istilah yang digunakan dalam bahasa Belanda disebut “leer plan” artinya rencana pelajaran, dan istila curriculum dalam bahasa Inggris kurang familiar dikalangan masyarakat. Sifat bersifat politisi adalah satu ciri kurikulum 1947 karena dari awalnya berkiblat pendidikan belanda yang durubah untuk kepentingan nasional. Dapat di pahami bahwa sistem pendidikan kolonial dikenal dengan sistem yang sangat diskriminatif. Sekolah-sekolah dibangun dengan membedakan layanan pendidikan bagi anak-anak Belanda, anak-anak timur asing dan anak pribumi. Golongan pribumi dibagi menjadi golongan strata sosial bawah dan priyai. ${ }^{8}$

Pelaksanaan kurikulum 1947 tidak menekankan pada aspek kognitif namun hanya mengutamakan pendidikan karakter seperti membangun rasa nasionalisme. Aspek selanjutnya yang menjadi tujuan utama dalam kurikulum Rentjana pelajaran 1947. Struktur program dalam Rentjana pelajaran 1947 dibagi menjadi dua bagian, yaitu struktur program menggunakan bahasa daerah dan bahasa Indonesia. Adapun struktur mata pelajaran pada kurikulum Rentjana pelajaran 1947 bersifat terpisah-pisah atau dalam konteks kurikulum disebut dengan separated curriculum. ${ }^{9}$

${ }^{7}$ Arif Munandar, Pengantar kurikulum, (Yogyakarta : CV Budi Utama, 2012), hlm. 50.

8 Alhamuddin, Politik Kebijakan Pengembangan Kurikulum ......., hlm. 46-47. 
Berikut ini ciri-ciri Kurikulum 1947:

a. Sifat kurikulum kurikulum mata pelajaran yang terpisah (1946-1947)

b. Penganar disekolah menggunakan

c. Dalam jenjang pendidikan memiliki jumlah mata pelajaran yang berbeda. ${ }^{10}$

Berdasarkan deskripsi diatas, dapat dipahami bahwa konsep kurikulum Rentjana pelajaran 1947 masih bersifat sederhana, yaitu hanya sebagai rencana pembelajaran yang akan dilaksanakan atau di implementasikan dalam pembelajaran dikelas. Dengan demikian bahwa kurikulum belum mencakup seluruh pengalaman yang akan diperoleh peserta didik baik dalam kelas maupun luar kelas.

\section{b. Kurikulum 1952 "Rentjana Pelajaran Terurai 1952”}

Pada tahun 1952 dilakukan perbaikan pada kurikulum di Indonesa yang kemudian dikenal dengan kurikulum 1952. Kurikulum ini lebih memerinci setiap mata pelajaran yang kemudian di beri nama “Rentjana Pelajaran Terurai 1952” dan belum menggunakan istilah kurikulum. Kerangka kurikulum 1952 reatif sama dengan kurikulum 1947. Namun demikian, sistem pendidikan nasional sudah menjadi tujuan kurikulum ini. UU No. 4 tahun 1950 tentang dasar-dasar pendidikan dan pengajaran di sekolah mempengaruhi munculnya kurikulum 1950 ini. $^{11}$

Bagaimana cara hidup yang baik sangat penting untuk di hubungkan dengan karakter yang menjadi pintu tujuan sebuah perbaikan kurikulum. Dan kehidupan nyata di masyarakat (tematik) menjadi hal yang paling menonjol dan sekaligus menjadi ciri khas kurikulum 1952 ini. Dalam konteks Rentjana Pelajaran Terurai 1952, mata pelajaran diklasifikasikan dalam lima kelompok bidang study, yaitu : 1) Moral, 2)

9 Ibid, hlm. 47-48.

10 Dicky Wirianto, Perspektif Historis Transformasi Kurikulum di Indonesia, Jurnal, Islamic Studies Journal, Vol. 2 No. 1 Januari - Juni 2014.

11 Alhamuddin, Politik Kebijakan Pengembangan Kurikulum ......., hlm. 48. 
Kecerdasan, 3) Emosionalistik / artistik 4) Keterampilan dan 5) Jasmani. $^{12}$

\section{c. Kurikulum 1964 Rentjana Pendidikan 1964}

Kurikulum di Indonesia pada tahun 1964 mengalami penyempurnaan kembali. Konsep pembelajaran aktif, kreatif dan produktif menjadi isu-isu yang dikembangkan pada Rentjana Pendidikan 1964. Konsep tersebut mewajibkan setiap sekolah membimbing anak agar mampu memikirkan sendiri pemecahan pemecah masalah (problem solving) terhadap berbagai masalah yang ada. Dengan demikian dapat dipahami bahwa konsep kurikulum pada era ini lebih bersifat bagaimana peserta didik bersikap aktif, kreatif dan produktif menemukan solusi terhadap berbagai masalah yang berkembang dan ada di masyarakat. Cara belajar yang digunakan kurikulum 1964 adalah sebuah metode yang disebut dengan gotong royong terpimpin. Selain itu, hari krida ditetapkan pada hari sabtu oleh pemerintah. Hari Krida artinya pada hari tersebut peserta didik diberikan kebebasan untuk berlatih berbagai kegiatan disesuaikan dengan minat dan bakat masing-masing. Seperti kegiatan kebudayaan, kesenian, olahraga dan berbagai bentuk permainan. Kurikulum 1964 direncana agar mampu menjadi alat untuk mencetak manusia Indonesia Pancasilais yang sosialis dengan sifat-sifat seperti yang termaktub dalam Tap MPRS No. II tahun 1960. ${ }^{13}$

\section{Masa Orde Baru (1966-1998)}

\section{a. Kurikulum 1968}

Sifat politis melekat erat pada awal munculnya kurikulum 1968, mengganti kurikulum 1964 yang dicitrakan sebagai hasil dari pemerintahan “Orde Lama”. Jika dilihat dari aspek tujuannya, upaya untuk meningkatkan rasa cinta tanah air, kuat dan sehat jasmani, mempertinggi kecerdasan dan ketrampilan jasmani, moral, budi pekerti dan keyakinan beragama lebih di tekankan pada kurikulum 1968.

12 Ibid, hlm. 48-49.

13 Ibid, hlm. 49-50. 
Perubahan dari pancawardana menjadi pembinaan jiwa pancasila terjadi pada kurikulum 1968. UUD 1945 menjadi kiblat dalam penerapan kurikulum ini secara murni dan konsekuen. Jumlah dari keseluruhan matapelajaran pada kurikulum 1968 berjumlah sembilan mata pelajaran. Pelajaran dikurikulum ini bersifat teoritis, tidak mengaitkan dengan permasalahan nyata yang terjadi di lapangan. ${ }^{14}$

Kelahiran kurikulum 1968 karena adanya pertimbangan politik ideologis yang dianut pemerintah saat itu, yaitu orde baru. Correlated subject curriculum menjadi ciri khas struktur kurikulum 1968, artinya bahwa materi pada jenjang pendidikan rendah memiliki korelasi untuk jenjang pendidikan pada jenjang selanjutnya. ${ }^{15}$

Kurikulum 1968 identik dengan muatan mata pelajaran teoritis, tidak berkaitan dengan ketentuan obyektif dilapangan atau kehidupan nyata (tematik) adapun metode pembelajaran yang digunakan dalam kurikulum ini sangat tergantung oleh ilmu pendidikan dan psikologi pada akhir tahun 1960-an.

\section{b. Kurikulum 1975}

\section{1) Latar Belakang Kelahiran Kurikulum 1975}

Pembangunan nasional melatarbelakangi kelahiran kurikulum 1975 akibat dari banyaknya perubahan-perubahan yang terjadi, terutama sejak tahun 1969. Banyak faktor-faktor yang mempengaruhi program maupun kebijakan pemerintah yang mengakibatkan pembaharuan tersebut. ${ }^{16}$

Kurikulum 1975 merupakan kurikulum yang bersifat sentralistik atau dibuat oleh pemerintah pusat dan sekolah-sekolah hanya menjalankan. ${ }^{17}$ Kurikulum 1975 berprinsip tujuan dari pendidikan harus efektif dan efisien. Kurikulum 1975 banyak mendapatkan kritik dari pelaksana di lapangan. Guru dibuat sibuk

14 Ibid, hlm. 51-52.

15 Ibid, hlm. 52.

16 Ibid, hlm. 53.

17 Muhammad Nurhalim, Analisis Perkembangan Kurikulum Di Indonesia (Sebuah 
menulis perincian apa yang akan dicapai dari setiap kegiatan pembelajaran $^{18}$

\section{2) Prinsip Implementasi Kurikulum 1975}

Kurikulum 1975 sebagai pengganti kurikulum 1968 memiliki beberapa prinsip pelaksanaan, diantarannya adalah sebagai berikut: ${ }^{19}$

1) Pendidikan harus berorientasi pada tujuan.

2) Menggunakan pendekatan integratif dalam arti bahwa agar tujuan pembelajaran menjadi tujuan yang inyegratif

3) Dalam daya dan waktu menekankan keefisien dan keefektifannya

4) Menganut pendekatan sistem instruksional yang dikenal dengan (PPSI). Perubahan tingkah laku peserta didik menjadi tujuan utama dari kurikulum ini

5) Stimulus dan respon yang dipengaruhi oleh psikologi tingkah laku. Karena tujuannya adalah perubahan tingkah laku maka teori pembelajaran yang digunakan adalah teori belajar behavioristik

\section{3) Pedoman dan Ketentuan Kurikulum 1975}

Kurikulum 1975 memuat beberapa pedoman dan ketentuan, yaitu: 1) Tujuan instruksional adalah suatu tujuan yang hendak dicapai lembaga dalam melaksanakan program pendidikan. Tujuan ini berlaku mulai sekolah dasar sederajat sampai dengan sekolah menengah atas sederajat; 2) Desain program kurikulum adalah suatu kerangka umum program pengajaran yang akan diberikan kepada setiap satuan pendidikan; 3) garis-garis program pengajaran,

4) Sistem Penyajian dengan Pendekatan Prosedur Pengembangan Sistem Instruksional (PPSI)

Pendekatan PPSI merupakan suatu konsep pembelajaran yang berasumsi bahwa proses belajar mengajar yang senantiasa 
diarahkan pada pencapaian tujuan. Selain itu, pendekatan PSSI merupakan suatu sistem yang saling berkaitan dari satu instruksi yang terdiri dari urutan, desain tugas yang progresif begi individu yang belajar. ${ }^{20}$

\section{5) Sistem Penilaian}

Sistem penilaian dalam kurikulum 1975 dilakukan setiap akhir pelajaran atau pada akhir satuan pembelajaran. Hal ini yang membedakan antara sistem penilaian pada kurikulum 1975 dan kurikulum sebelumnya. Sistem penilaian kurikulum ini dipengaruhi oleh pendekatan pembelajaran yang digunkaan dalam proses kegiatan belajar mengajar. Dengan sendirinya guru-guru dituntut melakukan penilaian pada setiap akhir satuan pembelajaran. ${ }^{21}$

\section{c. Kurikulum 1984 Kurikulum 1975 yang Disempurnakan}

Kurikulum 1984 merupakanpenyempurnaan dari kurikulum 1975 dan mengunakan pendekatan proses. Dalam hal ini faktor tujuan tetap penting messkipun sudah menggunakan pendekatan proses. Kurikulum ini juga sering disebut "Kurikulum 1975 yang disempurnakan". Subjek belajarnya adalah siswa. Model seperti ini yang dinakan aktif learning karena siswa yang akan selalu aktif dalam pembelajaran. Dari mengamati sesuatu, mengelompokkan, mendiskusikan, hingga melaporkan. Namun banyak sekolah yang menerapkan dengan baik dan alhasil siswa tidak melaksanakan pembelajaran dengan baik dan hanya gaduh di kelas. ${ }^{22}$

\section{d. Kurikulum 1994 (Separate Subject Curriculum)}

Kurikulum 1975 dan kurikulum 1984 dipadukan menjadi kurikulum 1994. Kurikulum 1994 dilaksanakan sesuai dengan UndangUndang no.2 tahun 1989 tentang Sistem Pendidikan Nasional. Pada kurikulum ini terjadi perubahan dari sistem semester ke sistem catur wulan. Dengan sistem caturwulan yang pembagiannya dalam satu tahun

19 Ibid, hlm. 54.

${ }^{20}$ Ibid, hlm. 55-56.

${ }^{21}$ Ibid, hlm.57.

${ }^{22}$ Alhamuddin, Sejarah Kurikulum Indonesia (Studi Analisis Kebijakan Pengembangan 
menjadi tiga tahap diharapkan dapat memberi kesempatan bagi siswa untuk dapat menerima materi pelajaran cukup banyak. Tujuan pengajaran kurikulum ini yaitu lebih berorientasi pada materi pelajaran dan keterampilan menyelesaikan soal dan pemecahan masalah. ${ }^{23}$

Tujuan dan proses kurang berhasil dipadukan. Muatan nasional dan muatan lokah sangat banyak porsinya. Materi muatan lokal disesuaikan dengan kebutuhan daerah masing-masing, misalnya bahasa daerah kesenian, keterampilan daerah, dan lain-lain. Berbagai kepentingan kelompokkelompok masyarakat juga mendesak agar isu-isu tertentu masuk dalam kurikulum. Akhirnya, Kurikulum 1994 menjadi kurikulum yang super padat dan hasilnya juga kurang bagus. Berdasarkan study dokumentasi yang telah dijelaskan dalam bukunya Hari Suderadjat, kurikulum 1994 dapat dikemukakan bahwa kurikulum tersebut mempunyai beberapa kekurangan dan kelebihan. ${ }^{24}$

\section{1) Kelemahan Kurikulum 1994}

Kurikulum 1994 merupakan kurikulum yang berorientasikan pada mata pelajaran yang dikenal dengan yang dikenal dengan sebutan Separate Subject Curriculum, yang di organisasikan dalam mata pelajaran yang terpisah-pisah sehingga sering juga disebut sebagai Separate Subject Curriculum. Secara umum kurikulum ini mempunyai beberapa kelemahan antara lain yaitu $:^{25}$

1) Garis-garis program pembelajaran diorganisasikan dalam mata pelajaran sesuai dengan disiplin keilmuan. Organisasi kurikulum seperti ini dapat menghilangkan kesatuan bidang study, yang mengakibatkan tidak adanya perolehan yang integral pada siswa.

Kurikulum, Jurnal, Volume 1, Nomor 2, Oktober 2014.

${ }^{23}$ Iramdan \& Lengsi Manurung, Jurnal Ilmiah Wahana Pendidikan, Jurnal, Vol. 5, No.2, April 2019.

${ }^{24}$ Hari Suderajat, Implementasi Kurikulum Berbasis Kompetensi (KBK), (Bandung : CV Cipta Cekas Grafika, 2004), hlm. 6

25 Ibid, hlm. 6 
2) Pembelajaran kurang disingkronkan dengan aspek sosial yang itu sangat penting untuk dirinya. Karena pada akhirnya mereka harus bergaul dengana lingkungan sosialnya

3) Materi pembelajaran hanya fokus pada hafalan saja dari ilmuan terdahulu dan tidak memahami kandungannya. Dari situ dapat dilihat anak tidak mengkritisi apa yang mereka dapatkan namun hanya menghafalkan teori yang ada. Dengan begini dalam pembelajaran ini anak menjadi pasif.

Dibawah ini adalah kekurangan dari kurikulum 1994 yaitu sebagai berikut :

1) Materi bahan ajar sangat banyak kurang di sesuaikan dengan jam mata pelajarannya.

2) Kurikulum disuatu yang sesuai dengan potensi daerah tidak memanfaatkan siswa yang mempuyai keahlian sesuai dengan potensi daerahnya.

3) Ada beberapa mata pelajaran yang belum sinkron dengan kehidupan dan lingkungan, terutama yang berhubungan dengan bidang keilmuan lain atau perkembangan ilmu pengetahuan dan teknologi.

4) Kurang mengembangkan daya fikir dalam pengembangan strategi belajar

5) Masih ada susunan yang kurang sistematis padahal yang namanya kurikulum semuanya harus tertata rapidan sistematis

6) Saling ketergantungan antara pokok bahasan antar mata pelajaran sering tidak terjadi, misal antara mata pelajaran matematika dan fisika, sehingga dampak adanya mata pelajaran fisika yang sulit dipelajari karena pokok bahasan pada matematika belum diberikan.

7) Pada beberapa mata pelajaran tertentu ada materi esensial yang kurang dan disisi lain kelebihan materi yang kurang esensial. 


\section{2) Kemudahan Kurikulum 1994}

Di samping kelemahan yang disebutkan diatas kurikulum 1994 memiliki beberapa kemudahan antara lain yaitu : ${ }^{26}$

1) Dalam dokumen kurikulum materi sudah di siapkan secara keseluruhan maka guru sangat mudah dalam menyusun mata pelajaran yang akan diajarkan.

2) Setiap mata pelajaran berdiri sendiri maka guru mudah untuk merubahnya.

3) Karena berbasiss aspek kognitif dalam penilaian maka sangat mudah di lakukan oleh guru

Kurikulum 1994 memiliki prinsip Link and Match yaitu prinsip tentang pentingnya keterkaitan pendidikan dengan dunia kerja atau industri. Sekolah harus mampu menyiapkan tenaga-tenaga kerja yang terampil yang dibutuhkan oleh industri. Sebaliknya dunia industri juga harus bersinergi dengan lembaga-lembaga pendidikan. Pada akhirnya kurikulum ini banyak dikritik karena pendidikan menjadi kepanjangan tangan dari proses industrialisasi dan tidak memanusiakan manusia (dehumanisasi). ${ }^{27}$

\section{Masa Revormasi (1999 - Sekarang)}

\section{a. Kurikulum 2004, "KBK (Kurikulum Berbasis Kompetensi)”}

Kurikulum berbasis kompetensi (KBK) adalah suatu konsep pendekatan, strategi kurikulum yang menekankan pada penguasaan berbagai kompetensi tertentu. Peserta didik tidak hanya menguasai pengetahuan dan pemahaman, tetapi juga keterampilan, sikap, minat, motivasi dan nilai-nilai agar dapat melakukan sesuatu dengan penuh tanggung jawab. ${ }^{28}$

26 Ibid, hlm. 7.

27 Imam Machali, Kebijakan Perubahan Kurikulum 2013dalam Menyongsong Indonesia Emas Tahun 2045, UIN Sunan Kalijaga Yogyakarta, Jurnal Pendidikan IslamVol. III, No.1, Juni 2014/1435, DOI: 10.14421/jpi.2014.31.71-94.

28 Zainal Arifin, Konsep dan Model Pengembangan Kurikulum, (Bandung : PT Remaja Rosda Karya, 2011), hlm. 154 
1. Dasar pemikiran untuk menggunakan konsep kompetensi dalam kurikulum $^{29}$

1) Kompetensi berkenaan dengan kemampuan siswa melakukan sesuatu dalam berbagai konteks

2) Kompetensi menjelaskan pengalaman belajar yang dilakukan siswa untuk menjadi kompeten

3) Kompetensi merupakan hasil belajar (learning outcomes) yang menjelaskan hal-hal yang dilakukan siswa setelah melalui proses pembelajaran

4) Kendala yang dirasakan oleh siswa guru harus selalu memantau dan mengarahkan siswa agar kendala yg dialami bisa teratasi

\section{Ciri-ciri kurikulum berbasis kompetensi}

Depdiknas (2002) menjelaskan ciri-ciri kurikulum berbasis kompetensi yaitu: ${ }^{30}$

1) Memperhatikan apa yang sah diperoleh siswa selama dilaksanakan KBM

2) Hasil akhir dari sebuah pembelajaran adalah anak mempunyai agama dan keterampilan

3) Metode pembelajarannya bermacam-macam

4) Sumber belajar tidak hanya mengandalkan guru namun dari segala sesuatu yang mengandung edukasi

5) Penilaian berdasarka proses yang dilaui siswa dan hasilnya

b. Kurikulum 2006, “KTSP (Kurikulum Tingkat Satuan

\section{Pendidikan)"}

Salah satu rujukan dalam pengembangan kurikulum di Indonesia adalah kurikulum KTSP. Pencapaian kompetensi adalah orientasi dari KTSP, maka dari itu KTSP sering di sebut dengan KBK yang disempurnakan. Unsur standar kompetensi dan kompetensi dasar yang melekat pada KBK serta adanya prinsip yang sama dalam pengelolaan 
kurikulum yakni yang disebut dengan Kurikulum Berbasis Sekolah (KBS)..$^{31}$

KTSP mempunyai karakteristik yang sama dengan KBK yaitu guru bebas untuk melakukan perubahan, revisi dan penambahan dari standar yang sudah di buat pemerintah, mulai dari tujuan, visi-misi, struktur dan muatan kurikulum, beban belajar, kalender pendidikan sampai pengembangan silabus. ${ }^{32}$

Badan standar Nasional Pendidikan (BSNP) telah membuat Standar Kompetensi dan kompetensi dasar, yang diturunkan dari Standar Kompetensi Lulusan (SKL), yang di jadikan rujukan harus dari kompetensi inti dan Standar kelulusan sedangkan yang menjadi prinsip pengembangan adalah KBS yang dirancang untuk memberdayakan daerah dan sekolah dalam merencanakan, melaksanakan dan mengelola serta menilai proses dan hasil pembelajaran sesuai dengan daerahnya masing-masing. KTSP lahir dari semangat dari daerah-daerah bahwasannya pendidikan tidak hanya menjadi tanggung jawab pemerintah pusat saja melainkan juga menjadi tanggung jawab pemerintah daerah, oleh sebab itu dilihat dari pola atau model kurikulum pengembangannya KTSP merupakan salah satu model kurikulum bersifat desentralisasi. $^{33}$

\section{a. Landasan Penyusunan Kurikulum KTSP}

1) UU Nomor 20 Tahun 2003 tentang Sistem Pendidikan Nasional

2) PP Nomor 19 Tahun 2005 tentang Standar Nasional Pendidikan

3) Permendiud Nomor 22 Tahun 2006 tentang standar isi

4) Permendikbud Nomor 23 Tahun 2006 tentang Standar Kompetensis Lulusan

31 Wina Sanjaya, Kurikulum dan Pembelajaran : Teori dan Praktik Pengembangan Kurikulum Tingkat Satuan Pendidikan (KTSP), (Jakarta : Prenadamedia Group, 2008), hlm. 127.

32 Herman Zaini, Karakteristik Kurikulum 2013 dan Kurikulum Tingkat Satuan Pendidikan (KTSP), Program Studi Pendidikan Agama Islam Fakultas Ilmu Tarbiyah dan Keguruan UIN Raden Fatah Palembang, Jurnal Idaroh Vol.1 No.1 Juni 15-31.

33 Wina Sanjaya, Kurikulum dan Pembelajaran ......, hlm. 128. 
5) Permendikbud Nomor 24 Tahun 2006 dan Nomor 6 Tahun 2007 tentang Pelaksanaan Permendiknas Nomor 22 dan 23 tahun 2006

6) Permendiknas Nomor 20 tahun 2007 tentang Standar Penilaian Pendidikan $^{34}$

b. Konsep Dasar KTSP dan Karakteristik Kegiatan

\section{Pembelajarannya}

Konsep dasar KTSP meliputi 3 aspek yang saling berkaitan yaitu : ${ }^{35}$

1) Kegiatan pembelajran

2) Penilaian

3) Pengelolaan kurikulum berbasis sekolah

Sedangkan menurut Kunandar dalam bukunya Abdullah Idi karakteristik pembelajaran dalam KTSP adalah sebagai berikut : ${ }^{36}$

1) KTSP menuntun siswa untuk mengembangkan ilmu pengetahun, minat, bakat yang akhirnya akan membentuk siswa yang mempunyai kemandirian dan ketrampilan

2) KTSP berorientasi pada hasil belajar dan keberagamaan

3) Strategi pembelajaran yang digunakan beraneka ragam

4) Sumber belajar bukan hanya guru namun bisa teman sekelasnya, buku-buku film yang mengandung edukasi

5) Penilaian dilihat dari proses han hasilnya pada suatu targer pencapaian kompetensi

\section{c. Kurikulum 2013}

Kurikulum KTSP dianggap belum sempurna dan masih banyak kekurangan, apalagi saat ini adalah era digital yang apa-apa bisa dilakukan dengan teknologi maka KTSP harus segera dirubah menjadi kurikulum 2013. Berkembangnya teknologi adalah salah satu alasan yang relevan untuk menyempurnakan sebuah kurikulum. Sejarah pergantian

34 Suparlan, Tanya Jawab Pengembangan Kurikulum....., hlm. 99.

35 Ibid, hlm. 97.

36 Abdullah Idi, Pengembangan Kurikulum Teori \& Praktik, (Yogyakarta : Ar-ruzz Media, 2013), hlm. $333-334$. 
dan perubahan kurikulum tidak terlepas dari sejarah yang menaunginya. Sejarah yang melatarbelakangi lahirnya kurikulum KTSP merupakan bentuk implementasi Undang-undang No. 20 tahun 2003 tentang Sistem Pendidikan Nasional. Substansi kurikulum ini adalah peraturan pemerintah No.19 tahun 2005 tapi isi dan arah pengembangan pembelajaran masih memiliki keberhasilan, karakteristik dalam paket kompetensi yang ada pada KTSP yang memiliki kesamaan juga dengan karakteristik kurikulum KBK. ${ }^{37}$

Berkaitan dengan pengembangan kurikulum, kurikulum 2013 lebih menekankan pada pendidikan karakter, dengan harapan melahirkan insan yang produktif, kreatif, inovatif dan berkarakter. Meningkatkan proses dan hasil belajar yang diarahkan kepada pembentukan budi pekerti dan peserta didik yang berakhlak mulia sesuai dengan standar kompetensi lulusan pada setiap satuan pendidikan adalah tujuan pendidikan karakter pada kurikulum 2013. Kurikulum 2013 menekankan pengembangan kompetensi pengetahuan, ketrampilan, dan sikap anak didik secara holostik. Kompetensi pengahuan, ketrampilan dan sikap ditentukan oleh rapor dan merupakan penentuan kenaikan kelas dan kelulusan anak didik. ${ }^{38}$

\section{a. Karakteristik kurikulum 2013}

Masing-masing kurikulum memiliki karakteristik tersendiri, demikian halnya dengan kurikulum 2013 yang dirancang oleh pemerintah. Adapun kurikulum 2013 dirancang dengan karakteristik sebagai berikut : 1) Mengembangkan secara seimbang antara kognitif, afektif dan psikomotor; 2) Siswa menerapkan apa yang sudah di dapat disekolah dalam kehidupanya sehari-hari; 3) Mengembangkan afekti, kognitif dan psikomotorik serta menerapkannya dalam berbagai situasi di sekolah dan masyarakat; 4) Memberi kesempatan yang banyak kepada siswa untuk 
mengembangkan aspek afekti, kognitif dan psikomotorik; 5) Kompetensi inti dijabarkan menjadi kompetensi dasar; 6) Kompetensi dasar yang diturunkan dari kompetensi inti harus sesuai dan sinkron; 7) Kompetensi dasar dikembangkan didasrkan pada prinsip akumulatif, saling memperkuat dan memperkaya antar mata pelajaran dan jenjang pendidikan (organisasi horisontal dan vertikal). ${ }^{39}$

\section{b. Landasan pengembangan kurikulum 2013}

Landasan filosofis, yuridis dan konseptual pengembangan kuikulum 2013 sebagai berikut: ${ }^{40}$

1) Landasan filosofis

a) Berbagai Etika dasar dalam pembangunan pendidikan adalah filosofis pancasila

b) Filosofis pendidikan yang berbasis pada nilai-nilai fundamental, nilai akademik, kebutuhan peserta didik, dan masyarakat

2) Landasan yuridis

a) RPJMM 2010-2014 Sektor Pendidikan, tentang Perubahan Metodologi pembelajaran dan Penataan Kurikulum

b) PPNo. 19 tahun 2005 Tentang Stanndar Nasional Pendidikan

c) INPRES No 1 Tahun 2010 tentang Percepatan Pelaksanaan Prioritas Pembangunan Nasional, penyempurnaan kurikulum dan metode pembelajaran aktif berdasarkan nilai-nilai budaya bangsa untuk membentuk daya saing dan karakter bangsa

3) Landasan konseptual

a) Pendidikan sesuai dengan kehidupan di masyarakat.

39 Maas Shobirin, Konsep dan Implementasi Kurikulum 2013 di Sekolah Dasar, (Yogyakarta : Deepublish, 2016), hlm. 39-40.

40 Mulyasa Pengembangan dan Implementasi Kurikulum 2013, (Bandung : Rosda Karya, 2013), hlm. 64. 
b) Kurikulum berasaskan kompetensi dan karakter.

c) Pembelajaran disesuaikan dengan kondisinya

d) Pembelajaran aktif (student active learning)

e) Penilaian yang valid, utuh, dan menyeluruh

\section{Kesimpulan}

Kurikulum selalu dinamis dan senantiasa dipengaruhi oleh perubahan-perubahan dalam faktor yang mendasarinya. Tujuan pendidikan dapat berubah secara fundamental, bila suatu negara beralih dari negara yang dijajah menjadi perubahan yang menyeluruh.

Dalam sejarah perkembangan kurikulum di Indonesia telah tercatat sebanyak sebelas kali yaitu sejak tahun 1945, kurikulum pendidikan nasional telah mengalami perubahan pada tahun 1947, 1952, 1964, 1968, 1973, 1975, 1984, 1994, 1999, 2004, 2006 dan 2013. Yang dimana setiap kurikulumnya mempunyai kelebihan dan kekurangannya. Dan kurikulum ini dapat berubah kapanpun sesuai dengan kebutuhan pendidikan di Indonesia. 


\section{DAFTAR PUSTAKA}

Abdullah Idi, Pengembangan Kurikulum Teori \& Praktik, Yogyakarta: Ar-ruzz Media, 2013.

Alhamuddin, Politik Kebijakan Pengembangan Kurikulum di Indonesia Sejak Zaman Kemerdekaan Hingga Reformasi (1947-2013), Jakarta: Prenadamedia, 2019.

Alhamuddin, Sejarah Kurikulum Indonesia (Studi Analisis Kebijakan Pengembangan Kurikulum, Jurnal, Volume 1, Nomor 2, Oktober 2014.

Aslan, Hidden Curriculum: E-booksia Publisher, CV Pena Indis, 2019.

Dicky Wirianto, Perspektif Historis Transformasi Kurikulum di Indonesia, Jurnal, Islamic Studies Journal, Vol. 2 No. 1 Januari - Juni 2014.

Fitri Wahyuni, Kurikulum dari Masa Ke Masa, Jurnal, Al-Adabiya, Vol. 10 No.2, Juli - Desember 2015.

Hari Suderajat, Implementasi Kurikulum Berbasis Kompetensi (KBK), Bandung: CV Cipta Cekas Grafika, 2004.

Herman Zaini, Karakteristik Kurikulum 2013 dan Kurikulum Tingkat Satuan Pendidikan (KTSP), Program Studi Pendidikan Agama Islam Fakultas Ilmu Tarbiyah dan Keguruan UIN Raden Fatah Palembang, Jurnal Idaroh Vol.1 No.1 Juni 15-31.

Imam Machali, Kebijakan Perubahan Kurikulum 2013dalam Menyongsong Indonesia Emas Tahun 2045, UIN Sunan Kalijaga Yogyakarta, Jurnal Pendidikan IslamVol. III, No.1, Juni 2014/1435, DOI: 10.14421/jpi.2014.31.71-94.

Iramdan \& Lengsi Manurung, Jurnal Ilmiah Wahana Pendidikan, Jurnal, Vol. 5, No.2, April 2019.

Lismina, Pengembnagan Kurikulum di Sekolah dan Perguruan Tinggi, Ponorogo : Tim Uwais Inspirasi Indonesia, 2019.

Maas Shobirin, Konsep dan Implementasi Kurikulum 2013 di Sekolah Dasar, Yogyakarta: Deepublish, 2016.

Muhammad Nurhalim, Analisis Perkembangan Kurikulum di Indonesia (Sebuah Tinjauan Desain dan Pendekatan), Jurnal, INSANIA Vol.16, No.3 September-Desember 2011. 
Mulyasa Pengembangan dan Implementasi Kurikulum 2013, Bandung: Rosda Karya, 2013.

Prayogi, Rayindra Dwi, and Rio Estetika. "Kecakapan Abad 21: Kompetensi Digital Pendidik Masa Depan.” Jurnal Manajemen Pendidikan 14, no. 2 (2019).

Rosichin Mansur, Pengembangan Kurikulum Pendidikan Agama Islam Multikultural (Suatu Prinsip-prinsip Pengembangan), Jurnal Ilmiah Vicratina, Volume 10, No. 2, Nopember 2016.

Syamsul Bahri, Pengembangan Kurikulum Dasar dan Tujuannya, Jurnal Ilmiah ISLAM FUTURA, Volume XI, No. 1, Agustus 2011.

Wina Sanjaya, Kurikulum dan Pembelajaran: Teori dan Praktik Pengembangan Kurikulum Tingkat Satuan Pendidikan (KTSP), Jakarta: Prenadamedia Group, 2008.

Wiwin Fachrudin Yusuf, Implementasi Kurikulum 2013 (K-13) Pada Mata Pelajaran Pendidikan Agama Islam Sekolah Dasar (SD), Al-Murabbi: Jurnal Pendidikan Agama Islam, Volume 3 Nomor 2, Juni 2018.

Yunita Hariyani, Prinsip-prinsip Pengembangan Kurikulum dalam Upaya Meningkatkan Kualitas Pembelajaran, Jurnal Pendidikan Agama Islam, Vol. 2, No. 2, Juli-Desember 2018.

Yusuf, Achmad. 'Pengembangan Kurikulum PAI Berbasis Multikultural (Perspektif Psikologi Pembelajaran)'. AL MURABBI 4, no. 2 (25 May 2019): 251-74. https://doi.org/10.35891/amb.v4i2.1453.

Zainal Arifin, Konsep dan Model Pengembangan Kurikulum, Bandung: PT Remaja Rosda Karya, 2011. 
